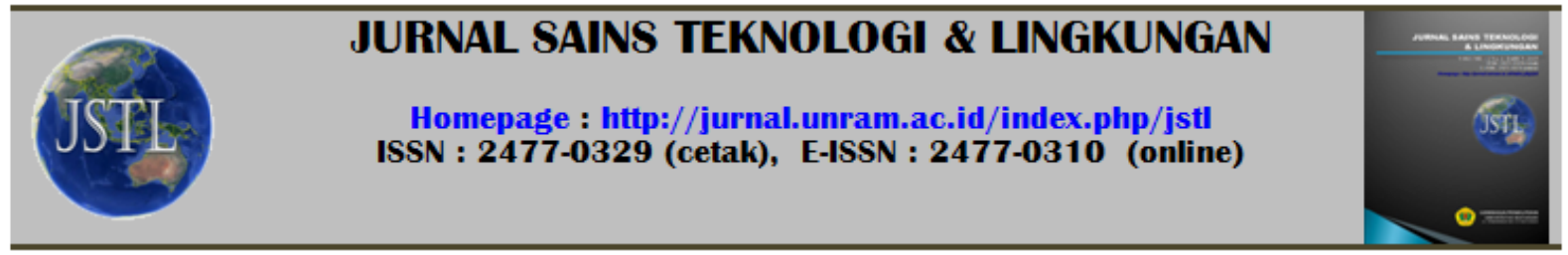

\title{
ANALISIS HUBUNGAN KETERSEDIAAN INFRASTRUKTUR DENGAN TINGKAT KEPADATAN PERMUKIMAN DI KOTA MATARAM
}

\begin{tabular}{|c|c|}
\hline Kata kunci : & Abstrak \\
\hline $\begin{array}{l}\text { Ketersediaan } \\
\text { infrastruktur, } \\
\text { kepadatan } \\
\text { permukiman, } \\
\text { analisisjalur }\end{array}$ & $\begin{array}{l}\text { Tingkat kepadatan permukiman di Kota Mataram tidak merata. Tingkat kepadatan } \\
\text { yang terjadi pada pusat kota sangat tinggi, ini dilihat dari meningkatnya jumlah } \\
\text { bangunan permukiman maupun pertumbuhan penduduk yang sangat pesat. Hal ini } \\
\text { menyebabkan terjadinya penurunan kualitas infrastruktur karena jumlah permukiman } \\
\text { tidak diimbangi dengan peningkatan infrastruktur, sedangkan kawasan permukiman di } \\
\text { pinggiran kota yang diharapkan menjadi kota baru banyak yang akhirnya gagal karena } \\
\text { kurangnya atau bahkan tidak adanya infrastruktur yang mendukung. Tujuan dari } \\
\text { penelitian ini adalah untuk mengidentifikasi ketersediaan infrastruktur yang ada pada } \\
\text { saat ini dan mengetahui hubungan antara ketersediaan infrastruktur dengan tingkat } \\
\text { kepadatan permukiman. Metode pengambilan data adalah dengan menggunakan } \\
\text { kuesioner. Sedangkan untuk menganalisis data, menggunakan analisis jalur yang } \\
\text { berguna untuk mengetahui hubungan antara ketersediaan infrastruktur dengan tingkat } \\
\text { kepadatan permukiman. Hasil identifikasi ketersediaan infrastruktur diketahui bahwa } \\
\text { untuk ketersediaan infrastruktur pada saat ini masih tidak memperhatikan tingkat } \\
\text { kepadatan permukiman. Dari hasil analisis data diketahui bahwa a) Ketersediaan } \\
\text { infrastruktur jalan memiliki korelasi langsung dengan tingkat kepadatan permukiman; } \\
\text { b) Ketersediaan infrastruktur sanitasi/ air limbah tidak memiliki korelasi langsung } \\
\text { dengan tingkat kepadatan permukiman; c) Ketersediaan infrastruktur persampahan } \\
\text { memiliki korelasi langsung dengan tingkat kepadatan permukiman; d) Ketersediaan } \\
\text { infrastruktur drainase memiliki korelasi langsung dengan tingkat kepadatan } \\
\text { permukiman. }\end{array}$ \\
\hline
\end{tabular}

Key words :
Infrastructure
availability,settlements
density, pathanlysis

\begin{abstract}
Density occurring uneven settlement, which the density in the city a growth fast the increasing of settlement buildings as well as rapid population growth, cause degradation of infrastructure quality because increase the settlements not balanced by an increase in infrastructure while developing of settlemet coastal area is expected to become a new city which eventually failed due to lack of or no infrastructure's support.Infrastructure availability is a very important factor in supporting densityof settlement in a region. The purpose of this study was to identify the availability of existing infrastructure and to determine the relationship between the availability of infrastructure to the density of settlements. Data collection for the reseach to purposes of the analysis carried out by using a sample. The sampling data method with a quesioner. Data Analyze using path analysis to get the relationship between the availability of infrastructure to the density of settlements. From the results of the identification of infrastructure availability known that the availability of the infrastructure was not affected by the settlement density. From the results of data analysis known that a) Availability of road infrastructure has a direct correlation with the level of settlement density; b) Availability of infrastructure sanitation / wastewater does not have a direct correlation with the level of settlement density; c) The availability of solid waste infrastructure has a direct correlation with the level of settlement density; d) availability of drainage infrastructure has a direct correlation with the level of settlement density.
\end{abstract}

(C2015 Universitas Mataram

Alamat koresponden penulis: E-mail : laksmyfortuna@gmail.com 


\section{PENDAHULUAN}

Kota Mataram menempati posisi penting bagi daerah sekitarnya. Terjadi peningkatan aktivitas menyebabkan bertambah padatnya permukiman di pusat kota dan terjadinya rambatan aktivitas tingkat kepadatan Kota Mataram menuju daerah pinggiran kota. Permukiman dapat diimplementasikan sebagai suatu tempat bermukim manusia yang menunjukkan suatu tujuan tertentu (Sastra \& Marlina, 2006). Kepadatan permukiman adalah perbandingan antara jumlah rumah tangga dengan luasannya di suatu wilayah pemukiman, dimana penduduknya mengelompok membentuk suatu pola tertentu yang sesuai dengan faktor yang mempengaruhi salah satunya adalah sarana dan prasarana yang tersedia (Kuswartojo, 2005).

Pranoto (2007) melakukan kajian terhadap hubungan kepadatan permukiman dengan ketersediaan infrastruktur. Metode yang digunakan adalah klasifikasi silang untuk mengetahui hubungan antara kepadatan permukiman dengan ketersediaan infrastruktur. Dari hasil analisis didapatkan kesimpulan bahwa hubungan yang didapat antara kepadatan permukiman dengan ketersediaan infrastruktur adalah jika permukiman tersebut padat, ketersediaan infrastrukturnya akan semakin banyak atau besar pula. Begitu juga sebaliknya, semakin rendah tingkat kepadatan suatu permukiman, maka ketersediaan infrastruktur semakin sedikit. Sedangkan pada penelitian ini menggunakan analisis jalur (path analysis) untuk mendapatkan hubungan antara ketersediaan infrastuktur dengan tingkat kepadatan permukiman pada permukiman dengan tingkat kepadatan tinggi dengan posisi di tengah kota yakni di Kelurahan Dayan Peken Kecamatan Ampenan, dan permukiman dengan tingkat kepadatan rendah dengan posisi di pinggiran kota yaitu Kelurahan Jempong Baru Kecamatan Sekarbela.

\section{TUJUAN PENELITIAN}

Tujuan penelitian ini adalah :

1. Mengidentifikasi ketersediaan infrastruktur eksisting pada permukiman di dua kawasan yaitu Kelurahan Dayan Peken dan Kelurahan Jempong Baru.
2. Mengetahui hubungan antara ketersediaan infrastruktur dengan tingkat kepadatan permukiman.

\section{METODOLOGI PENELITIAN}

Penelitian ini menggunakan perpaduan antara penelitian deskriptif dan penelitia kualitatif. Untuk mengidentifikasi ketersediaan infrastruktur dilakukan dengan melakukan observasi lapangan dan data sekunder. Pengumpulan data untuk keperluan analisis diperoleh dengan menggunakan sampel random purposif. Metode yang digunakan untuk pengambilan sampel adalah stratified random sample yaitu pengambilan sampel yang dilakukan secara acak dengan jumlah yang proporsional untuk setiap strata (golongan) dari populasi (Sugiyono, 2011). Penelitian dilakukan di awal tahun 2015 pada infrastruktur yang meliputi jaringan jalan, sanitasi, persampahan, dan drainase. Untuk mengetahui layanan infrastruktur dilakukan dengan metode wawancara kuesioner pada masyarakat di kawasan penelitian. Dan dari hasil tersebut dilakukan analisis statistik untuk dapat mengetahui apakah ada hubungan antara ketersediaan infrastruktur dengan tingkat kepadatan permukiman.

Tahapan-tahapan penelitian meliputi sebagai berikut :

\section{Penetapan variabel}

Pengidentifikasian variabel berdasarkan studi literatur yang berkaitan, kemudian ditetapkan variabel yang akan diteliti dan dituangkan dalam bentuk kuesioner . Data dikumpulkan dengan menggunakan kuisioner dan wawancara dengan responden (X1 sampai X4) dan Y diperolah dari masyarakat terkait. Data sikap (X1 sampai X4) dikuantitatifkan dengan penilaian skala likert $(1=$ sangat tidak baik, 2 = kurang baik, $3=$ tidak tahu, $4=$ baik, dan $5=$ sangat baik). Data $Y$ juga diukur dengan skala yang sama (Misbahudin dan Iqbal , 2013).

\section{Uji validitas dan uji reliabilitas}

Informasi yang didapat dari kuesioner perlu diuji validitas dan reabilitasnya (Trihendradi, 2012). Uji validitas yang digunakan adalah Pearson Correlation.

Hipotesis:

H_0 = variabel-variabel instrumen tidak valid

H_1 = variabel-variabel instrumen valid

Uji Statistik: 
Dalam uji validitas Pearson Correlation rumus yang digunakan adalah:

$$
r_{x y}=\frac{n\left(\sum_{i=1}^{k} X_{i} Y_{i}\right)-\left(\sum_{i=1}^{k} X_{i}\right)\left(\sum_{i=1}^{k} Y_{i}\right)}{\sqrt{\left\{n \sum_{i=1}^{k} X_{i}^{2}-\left(\sum_{i=1}^{k} X_{i}\right)^{2}\right\}\left\{n \sum_{i=1}^{k} Y_{i}^{2}-\left(\sum_{i=1}^{k} Y_{i}\right)^{2}\right\}}}
$$

dengan:

$$
\begin{array}{ll}
\mathrm{r}_{\mathrm{xy}} & \text { : koefisien korelasi } \\
\sum_{\mathrm{n}} X & : \text { jumlah skor item } \\
\mathrm{n} Y & : \text { jumlah skor total (semua item) }
\end{array}
$$

$\mathrm{k} \quad$ : jumlah pernyataan

Dasar pengambilan keputusan:

Jika nilai $\mathrm{r}_{\text {hitung }}<\mathrm{r}_{\text {tabel }}$ maka $\mathrm{H} 0$ diterima

Jika nilai $\mathrm{r}_{\text {hitung }}>\mathrm{r}_{\text {tabel }}$ maka $\mathrm{H} 0$ ditolak

Uji reliabilitas dari masing-masing faktor dengan menggunakan uji alpha-cronbach. Kuesioner dinyatakan reliabel jika mempunyai nilai koefisien alpha yang lebih besar dari 0,7 (Walizer, 1993). Adapun hipotesisnya adalah sebagai berikut :

$$
\begin{aligned}
& \text { H_0 : tidak reliabel } \\
& \text { H_1 : reliabel }
\end{aligned}
$$

Pada penelitian ini terdapat 5 variabel dengan total pernyataan adalah 37 item. Perhitungan nilai alpha-cronbach sebagai berikut:

$$
r=\frac{k}{k-1}\left\{1-\frac{\sum \sigma_{b}^{2}}{\sigma_{t}^{2}}\right\}
$$

dengan :

$\mathrm{r} \quad=$ koefisien reliabilitas instrumen

$\mathrm{k}=$ banyaknya butir pernyataan

$\sum \sigma_{\mathrm{b}}^{2}=$ total varian butir

$\sigma_{\mathrm{t}}^{2} \quad=$ varian total

Langkah pertama menghitung total varian butir $\sigma_{\mathrm{t}}^{2}:$

$$
\sigma_{b i}^{2}=\frac{\sum p_{i}^{2}-\frac{\left(\sum p_{i}^{2}\right)^{2}}{n}}{n}
$$

dengan :

$\sigma_{\text {bi }}^{2}=$ total varian butir ke-i

$\sum \mathrm{p}_{\mathrm{i}}^{2}=$ jumlah variabel ke-i

$\sum p_{i}^{2}=$ jumlah kuadrat variabel ke-i

$\mathrm{n} \quad=$ jumlah sampel

\section{Tahapan analisis jalur}

Adapun tahapan-tahapan dalam analisis jalur yang digunakan menurut Gunartha (2013) adalah sebagai berikut:

a. Menentukan Model dari variabel yang ada, merupakan pengembangan dari regresi berganda dengan menggunakan variabel exogenous, yaitu $\mathrm{x}$ dan satu variabel endogenous $\mathrm{y}$ dengan model numeriknya yaitu:

$$
\begin{aligned}
\mathrm{Y}=\mathrm{a}+\mathrm{b}_{1} \mathrm{X}_{1}+\mathrm{b} 2 \mathrm{X}_{2} & +\mathrm{b} 3 \mathrm{X}_{3}+\ldots . .+\mathrm{b},, \mathrm{X}, \text {, }(4) \\
\text { dengan: } & \\
\mathrm{Y}= & \text { Variabel Terikat } \\
\mathrm{Xi}= & \text { Variabel bebas/predictor } \\
\mathrm{A}= & \text { Konstanta/intersep } \\
\mathrm{bi}= & \text { Koefisien } \\
& \text { prediktor/koefisien regresi } \\
& \mathrm{Xi} \text { (menunjukkan angka } \\
& \text { peningkatan/ penurunan } \\
& \text { variabel terikat akibat dari } \\
& \text { perubahan variabel bebas). }
\end{aligned}
$$

b. Masing-masing substruktur dianalisis dengan analisis jalur mulai dari menghitung matrik korelasi, koefisien jalur, menghitung R2, dan menghitung residu.

\section{HASIL DAN PEMBAHASAN}

\section{Identifikasi Ketersediaan Infrastruktur}

\section{Jaringan Jalan}

Jaringan jalan utama pada kedua lokasi penelitian masih dalam kondisi baik dengan menggunakan lapisan aspal, rata-rata jalan lingkungan yang memiliki akses ke jalan utama memiliki lebar 2-4 meter dengan lapisan bervariasi yakni aspal, lapen, mapun paving block sehingga masih sesuai dengan Standar Pelayanan Minimal yang diatur dalam Kepmen Permukiman dan Prasarana Wilayah Nomor : 534/ KPTS/ M/ 2001 dimana untuk jalan lingkungan cakupan lebar yang memadai adalah 2 - 6 meter.

\section{Sanitasi}

Data sekunder mengenai ketersediaan jamban/ toilet rumah tangga tidak tersedia. Dari hasil kuesioner di setiap rumah tangga di permukiman Kelurahan Dayan Peken dan Kelurahan Jempong Baru telah memiliki jamban/ toilet yang dilengkapi dengan septictank untuk saluran pembuangan.

\section{Persampahan}

Pelayanan sampah masih tidak memadai, dimana pada Kelurahan Dayan Peken sudah tersedia TPS akan tetapi kapasitasnya 
kurang memadai karena peningkatan kepadatan permukiman tidak diikuti dengan peningkatan jumlah TPS. Pada Kelurahan Jempong Baru TPS yang ada masih tidak memadai karena dari 11 lingkungan yang ada hanya memiliki 3 TPS swadaya masyarakat.

\section{Drainase}

Pada Kelurahan Dayan Peken, setiap lingkungan memiliki drainase namun di beberapa lingkungan dijumpai drainase hanya ada di jalan utama, pada jalan antar lingkungan masih banyak yang tidak memiliki drainase yang mengakibatkan sering terjadinya genangan air. Untuk Kelurahan Jempong Baru, masih banyak wilayah yang belum memiliki drainase sehingga masuk dalam lokasi rawan banjir yang ditangani oleh pemerintah Kota Mataram.

\section{Analisis Korelasi}

\section{Penetapan variabel}

Penetapan variabel didapatkan dari berbagai sumber literatur ditampilkan dalam Tabel 1 dihawah ini

\begin{tabular}{|l|l|}
\multicolumn{2}{|c|}{ Tabel 1. Variabel-variabel Penelitian } \\
\hline \multicolumn{1}{|c|}{ VARIABEL } & \multicolumn{1}{c|}{ INDIKATOR } \\
\hline Jalan $\left(\mathrm{X}_{1}\right)$ & - Kondisi \\
& - Aksesibilitas \\
& - Kapasitas \\
\hline Sanitasi $\left(\mathrm{X}_{2}\right)$ & - Kondisi jamban/ toilet/ septictank \\
& - Kapasitas bak pembuangan \\
& - Pengelolaan limbah \\
\hline Sampah $\left(\mathrm{X}_{3}\right)$ & - Kondisi \\
& - Kapasitas TPS \\
& - Pelayanan sampah \\
\hline Drainase $\left(\mathrm{X}_{4}\right)$ & - Kondisi drainase \\
& - Kapasitas saluran \\
\hline Kondisi eksisting $\left(\mathrm{Y}_{1}\right)$ & \\
\hline Sosial ekonomi $\left(\mathrm{Y}_{2}\right)$ & \\
\hline Tingkat kepadatan permukiman $\left(\mathrm{Y}_{3}\right)$ & - Sarana dan prasarana \\
& \\
\hline
\end{tabular}

\section{Uji Validitas dan Reliabilitas}

Hasil uji validitas menggunakan rumus Pearson Correlation, yaitu $r$ hitung $>$ nilai $r$ tabel $(\alpha=0,05 ; n=50$ responden $)=0,279$ sehingga diketahui bahwa 5 variabel yang digunakan adalah valid. Hasil uji reliabilitas terhadap 37 variabel didapatkan nilai Cronbach's Alpha masing-masing 0.968 untuk Kelurahan Dayan Peken dan sebesar 0.979 untuk Kelurahan Jempong Baru, yang artinya lebih besar dari 0,7 (reliabel).

\section{Analisis Jalur}

Untuk mengetahui hubungan antara ketersediaan infrastruktur dengan tingkat kepadatan permukiman dilakukan dengan menggunakan analisis jalur, yakni dengan melakukan analisis pada masing-masing jenis infrastruktur/variabel terhadap tingkat kepadatan permukiman. Analisis jalur adalah suatu teknik untuk menganalisis hubungan sebab akibat yang terjadi pada regresi berganda jika variabel bebasnya mempengaruhi variabel tergantung tidak hanya secara langsung maupun tidak langsung (Sunyoto, 2012). Selain untuk mengetahui hubungan langsung antara masingmasing variabel dengan tingkat kepadatan permukiman, juga dapat diketahui hubungan tidak langsung antara variabel dengan memasukkan variabel kondisi eksisting wilayah dan sosial ekonomi sebagai variabel tidak langsung. Untuk itu dibuat diagram model analisis jalur untuk mencari hubungan antar variabel seperti berikut ini :

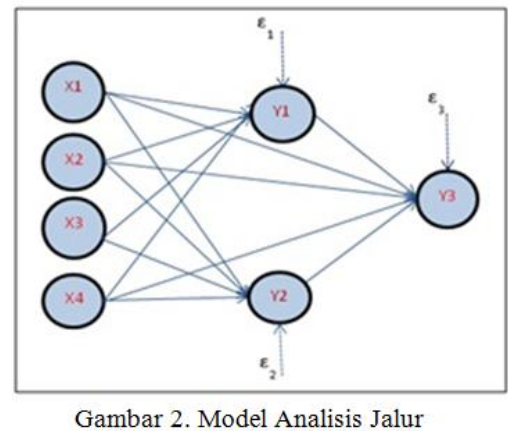

Gambar 2 memperlihatkan model analisis jalur yang digunakan dimana yang termasuk pengaruh langsung (direct effect) yang relevan dengan $\mathrm{Y}_{3}$, yakni:

- $\mathrm{X}_{1} \rightarrow \mathrm{Y}_{1}, \mathrm{X}_{2} \rightarrow \mathrm{Y}_{1}, \mathrm{X}_{3} \rightarrow \mathrm{Y}_{1}, \mathrm{X}_{4} \rightarrow \mathrm{Y}_{1}$; dengan $\mathrm{Y}_{2}\left(\mathrm{X}_{1} \rightarrow \mathrm{Y}_{2}, \mathrm{X}_{2} \rightarrow \mathrm{Y}_{2}, \mathrm{X}_{3} \rightarrow \mathrm{Y}_{2}, \mathrm{X} 4 \rightarrow \mathrm{Y} 2\right.$; dan dengan $\mathrm{Y}\left(\mathrm{Y}_{1} \rightarrow \mathrm{Y}_{3}\right.$ dan $\left.\mathrm{Y}_{2} \rightarrow \mathrm{Y}_{3}\right)$. Dengan kata lain pengaruh langsung merupakan pengaruh suatu peubah terhadap peubah yang dipengaruhi tanpa melalui peubah lain.

- Yang termasuk pengaruh tidak langsung (indirect effect) yang relevan dengan $\mathrm{Y}_{3}$ $\left(X_{1} \leftrightarrow Y_{1} \rightarrow Y_{3}, \quad X_{2} \leftrightarrow Y_{1} \rightarrow Y_{3}, \quad X_{3} \leftrightarrow Y_{1} \rightarrow Y_{3}\right.$, $\mathrm{X}_{4} \leftrightarrow \mathrm{Y}_{1} \rightarrow \mathrm{Y}_{3} \quad$ dan $\quad \mathrm{X}_{1} \leftrightarrow \mathrm{Y}_{2} \rightarrow \mathrm{Y}_{3}$, $\left.X_{2} \leftrightarrow Y_{2} \rightarrow Y_{3}, \quad X_{3} \leftrightarrow Y_{2} \rightarrow Y_{3}, \quad X_{4} \leftrightarrow Y_{2} \rightarrow Y_{3}\right)$. Dengan kata lain pengaruh tidak langsung merupakan pengaruh suatu peubah terhadap peubah yang dipengaruhi melalui peubah mediasi (intervening variable).

Untuk memudahkan pemahaman persamaan, model analisis jalur dibagi menjadi tiga substruktur diagram jalur dengan penjelasan sebagai berikut:

- Peubah bebas disebut peubah eksogenus (exogenous variables), yakni peubah yang 
menjadi penyebab (causal). Pada Teladan diatas, $\mathrm{X}_{1}, \mathrm{X}_{2}, \mathrm{X}_{3}$ dan $\mathrm{X}_{4}$ tergolong peubah ini.

- Peubah mediasi (intervening variable), yakni peubah yang menjadi mediasi. Peubah ini menjadi peubah respon dari peubah eksogenus, dan juga menjadi peubah eksogenus terhadap peubah respon berikutnya. Contoh $\mathrm{Y}_{1}$ dan $\mathrm{Y}_{2}$.

- Peubah tidak bebas akhir disebut peubah endogenus(endogenous variables), yakni merupakan peubah akibat (effect), misal peubah $\mathrm{Y}_{3}$.

Analisis hubungan ketersediaan infrastruktur dengan dianalisis dengan menggunakan statistik (Misbahudin dan Iqbal, 2013) sebagai berikut :

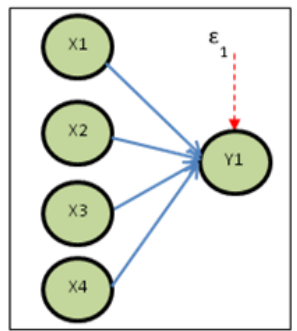

Gamb Gambar 3. Diagram Hubungan Substruktur 1 lubungan substruktur 1 dengan rantai kausal yang terbentuk yaitu $\mathrm{Y}_{1}$ dengan jalur jalur variabel $\mathrm{X}_{1}, \mathrm{X}_{2}, \mathrm{X}_{3}$, dan $\mathrm{X}_{4}$.

\section{a. Substruktur 1}

Berdasarkan diagram jalur model kausal substruktur 1 (Gambar 3) dibuat persamaan sebagai berikut:

$$
Y_{1}=\rho_{Y_{1} X_{1}} X_{1}+\rho_{Y_{1} X_{2}} X_{2}+\rho_{Y_{1} X_{3}} X_{3}+\rho_{Y_{1} X_{4}} X_{4}+\rho_{Y_{1} \varepsilon_{4}}
$$

Untuk mengetahui gambaran hubungan antar variabel kausal, maka dilakukan analisis korelasi dengan menggunakan SPSS dengan hasil sebagai berikut :

Kelurahan Dayan Peken :

$Y_{1}=0.38 X_{1}+0.24 X_{2}+0.13 X_{3}+0.16 X_{4}+0.426$ neiuranan Jempong baru

b

$Y_{1}=0.22 X_{1}+0.68 X_{2}+0.02 X_{3}+0.03 X_{4}+0.207$

Gambar

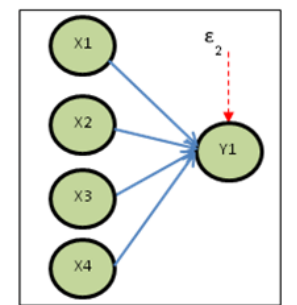

Substruktı Gambar 4. Diagram Hubungan Substruktur 2 ientuk:
Y2 dengan jalur jalur variabel $\mathrm{X} 1, \mathrm{X} 2, \mathrm{X} 3$, dan $\mathrm{X} 4$.

Berdasarkan diagram jalur model kausal substruktur 2 (gambar 6) dibuat persamaan sebagai berikut:

$$
Y_{2}=\rho_{Y_{2} X_{1}} X_{1}+\rho_{Y_{2}, X_{2}} X_{2}+\rho_{Y_{2} X_{3}} X_{3}+\rho_{Y_{2}} X_{4} X_{4}+\rho_{Y_{2}} \varepsilon_{2}
$$

Setelah dilakukan analisis korelasi dengan menggunakan SPSS didapatkan hasil sebagai berikut:

Kelurahan Dayan Peken

$Y_{2}=0.52 X_{1}+0.20 X_{2}+0.19 X_{3}+0.05 X_{4}+0.291$ neiuranan Jempong baru

$Y_{2}=0.24 X_{1}+0.65 X_{2}+0.10 X_{3}-0.01 X_{4}+0.214$

\section{c. Substruktur 2}

Gam

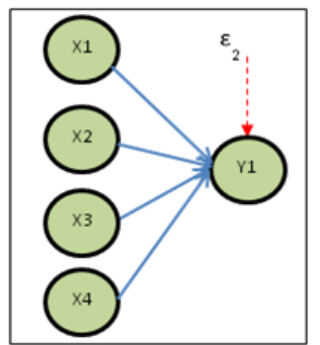

subs Gambar 4. Diagram Hubungan Substruktur 2 bentuk:

Y2 dengan jalur jalur variabel X1, X2, X3, dan $\mathrm{X} 4$.

Berdasarkan diagram jalur model kausal substruktur 2 (gambar 6) dibuat persamaan sebagai berikut:

$$
Y_{2}=\rho_{Y_{2} X_{1}} X_{1}+\rho_{Y_{2} X_{2}} X_{2}+\rho_{Y_{2} X_{3}} X_{3}+\rho_{Y_{2} X_{4}} X_{4}+\rho_{Y_{2}} \varepsilon_{2}
$$

Setelah dilakukan analisis korelasi dengan menggunakan SPSS didapatkan hasil sebagai berikut:

Kelurahan Dayan Peken

$$
\begin{aligned}
& Y_{2}=0.52 X_{1}+0.20 X_{2}+0.19 X_{3}+0.05 X_{4}+0.291 \\
& \text { Gamb Gambar 5. Diagram Hubungan Substruktur 3 hubungan } \\
& \text { substruktur dengan rantal kausal yang terbentuk: } \\
& Y 3 \text { dengan jalur jalur variabel X1, X2, } \\
& \text { Y3 }
\end{aligned}
$$


$\mathrm{X} 3, \mathrm{X} 4, \mathrm{Y} 1$, dan $\mathrm{Y} 2$. Berdasarkan diagram jalur model kausal substruktur 2 (gambar 7) dibuat persamaan sebagai berikut:

$Y_{3}=\rho_{Y_{3} X_{1}} X_{1}+\rho_{Y_{3} X_{2}} X_{2}+\rho_{Y_{3} X_{3}} X_{3}+\rho_{Y_{3} X_{4}} X_{4}+\rho_{Y_{3} Y_{1}} Y_{1}+\rho_{Y_{3} Y_{2}} Y_{2}+\rho_{Y_{3} \varepsilon_{3}}$

Setelah dilakukan analisis korelasi dengan menggunakan SPSS dengan hasil sebagaimana ditampilkan dibawah ini :

Kelurahan Dayan Peken:

$$
Y_{3}=0.27 X_{1}+0.04 X_{2}+0.13 X_{3}-0.01 X_{4}+0.29 Y_{1}+0.37 Y_{2}+0.047
$$

Kelurahan Jempong Baru:

$Y_{3}=0.41 X_{1}-0.09 X_{2}+0.19 X_{3}-0.06 X_{4}+0.46 Y_{1}+0.12 Y_{2}+0.062$

Dari Hasil analisis jalur yang didapatkan menggunakan SPSS Windows dapat dalam bentuk diagram model sebagai berikut:

\section{A. Kelurahan Dayan Peken}

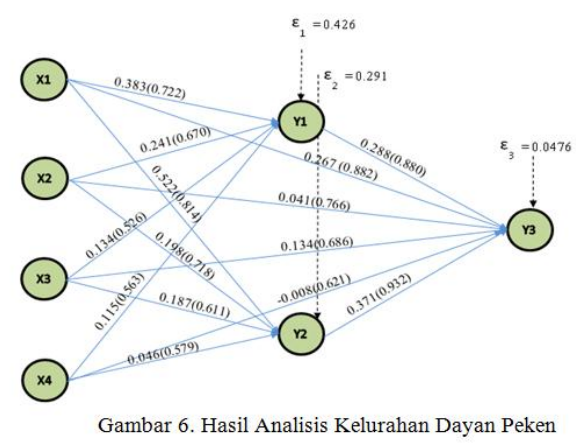

Dari Gambar 6 Hasil Analisis Jalur dapat diuraikan sebagai berikut:

1) Model rantai kausal pertama

$\mathrm{X}_{1}$ (jalan) memiliki korelasi langsung pada $\mathrm{Y}_{1}$ (kondisi eksisting) sebesar $0.383 ; \mathrm{X}_{2}$ (sanitasi) memiliki korelasi langsung pada $\mathrm{Y}_{1}$ (kondisi eksisting) sebesar $0.241 ; \quad \mathrm{X}_{3} \quad$ (persampahan) memiliki korelasi langsung pada $Y_{1}$ (kondisi eksisting) sebesar 0.134; $\mathrm{X}_{4}$ (drainase) memiliki korelasi langsung pada $\mathrm{Y}_{1}$ (kondisi eksisting) sebesar 0.115 ;

2) Model rantai kausal kedua

$\mathrm{X}_{1}$ (jalan) memiliki korelasi langsung pada $\mathrm{Y}_{2}$ (sosial Ekonomi) sebesar 0.522 $\mathrm{X}_{2}$ (sanitasi) memiliki korelasi langsung pada $Y_{2}$ (sosial ekonomi) sebesar 0.198; $\mathrm{X}_{3}$ (persampahan) memiliki korelasi langsung pada $\mathrm{Y}_{2} \quad$ (sosial ekonomi)sebesar $0.187 ; \quad \mathrm{X}_{4}$ (drainase) memiliki korelasi langsung pada $\mathrm{Y}_{2}$ (sosial ekonomi) sebesar 0.046;

3) Model rantai kausal ketiga

$\mathrm{X}_{1}$ (jalan) memiliki korelasi langsung pada $\mathrm{Y}_{3}$ (tingkat kepadatan permukiman) sebesar $0.267 ; \quad \mathrm{X}_{2}$ (sanitasi) memiliki korelasi langsung pada $\mathrm{Y}_{3} \quad$ (tingkat kepadatan permukiman) sebesar $0.041 ; \quad \mathrm{X}_{3}$ (persampahan) memiliki korelasi langsungpada $\mathrm{Y}_{3}$ (tingkat kepadatan permukiman) sebesar $0.134 ; \quad \mathrm{X}_{4}$ (drainase) memiliki korelasi langsung terhadap $\mathrm{Y}_{3}$ (tingkat kepadatan permukiman) sebesar $-0.008 ; \quad \mathrm{Y}_{1}$ (kondisi eksisting wilayah) berpengaruh langsung terhadap $\mathrm{Y}_{3}$ (tingkat kepadatan permukiman) sebesar 0.288; $\mathrm{Y}_{2}$ (sosial ekonomi) berpengaruh langsung terhadap $\mathrm{Y}_{3} \quad$ (tingkat kepadatan permukiman) sebesar 0.371 .

4) Pengaruh Tidak Langsung

$\mathrm{X}_{1}$ memberi pengaruh tidak langsung pada $\mathrm{Y}_{3}$ (tingkat kepadatan permukiman) melalui $\mathrm{Y}_{1}$ sebesar 0.383 $\mathrm{X} 0.288=0.110 ; \mathrm{X}_{2}$ memberi pengaruh tidak langsung pada $\mathrm{Y}_{3}$ (tingkat kepadatan permukiman) melalui $\mathrm{Y}_{1}$ sebesar $0.241 \times 0.288=0.069 ; \mathrm{X}_{3}$ memberi pengaruh tidak langsung pada $\mathrm{Y}_{3}$ (tingkat kepadatan permukiman) melalui $\mathrm{Y}_{1}$ sebesar $0.134 \mathrm{X} 0.288=$ $0.039 ; \mathrm{X}_{4}$ memberi pengaruh tidak langsung pada $\mathrm{Y}_{3}$ (tingkat kepadatan permukiman) melalui $\mathrm{Y}_{1}$ sebesar 0.115 $\mathrm{X} 0.288=0.033 ; \mathrm{X}_{1}$ memberi pengaruh tidak langsung pada $\mathrm{Y}_{3}$ (tingkat kepadatan permukiman) melalui $\mathrm{Y}_{2}$ sebesar $0.522 \times 0.371=0.194 ; \mathrm{X}_{2}$ memberi pengaruh tidak langsung pada $\mathrm{Y}_{3}$ (tingkat kepadatan permukiman) melalui $\mathrm{Y}_{2}$ sebesar $0.198 \times 0.371=$ $0.073 ; \mathrm{X}_{3}$ memberi pengaruh tidak langsung pada $\mathrm{Y}_{3}$ (tingkat kepadatan permukiman) melalui $\mathrm{Y}_{2}$ sebesar 0.187 $\mathrm{X} 0.371=0.069 ; \mathrm{X}_{4}$ memberi pengaruh tidak langsung pada $\mathrm{Y}_{3}$ (tingkat kepadatan permukiman) melalui $\mathrm{Y}_{2}$ sebesar 0.046 X $0.371=0.018$;

Dari hasil analisis dapat dijelaskan sebagai berikut : 
a) Ketersediaan infrastruktur jalan memiliki korelasi langsung dengan tingkat kepadatan permukiman;

b) Ketersediaan infrastruktur sanitasi/ air limbah tidak memiliki korelasi langsung dengan tingkat kepadatan permukiman;

c) Ketersediaan infrastruktur persampahan memiliki korelasi langsung dengan tingkat kepadatan permukiman;

d) Ketersediaan infrastruktur drainase memiliki korelasi langsung dengan tingkat kepadatan permukiman.

\section{B. Kelurahan Jempong Baru}

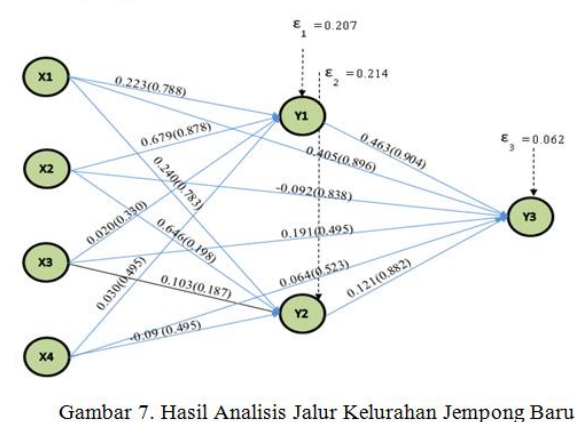

Dari Gambar 7 Hasil Analisis Jalur dapat diuraikan sebagai berikut:

1) Model rantai kausal pertama

$\mathrm{X}_{1}$ (jalan) memiliki korelasi langsung dengan $\mathrm{Y}_{1}$ (kondisi eksisting) sebesar $0.223 ; \mathrm{X}_{2}$ (sanitasi) memiliki korelasi langsung dengan $\mathrm{Y}_{1}$ (kondisi eksisting) sebesar 0.679; $\mathrm{X}_{3} \quad$ (persampahan) memiliki korelasi langsung dengan $\mathrm{Y}_{1}$ (kondisi eksisting) sebesar $0.020 ; \mathrm{X}_{4}$ (drainase) memiliki korelasi langsung dengan $\mathrm{Y}_{1}$ (Kondisi eksisting) sebesar 0.030 .

2) Model rantai kausal kedua

$\mathrm{X}_{1}$ (jalan) memiliki korelasi langsung dengan $\mathrm{Y}_{2}$ (sosial ekonomi) sebesar 0.240 ;

$\mathrm{X}_{2}$ (sanitasi) memiliki korelasi langsung dengan $\mathrm{Y}_{2}$ (sosial ekonomi) sebesar 0.646; $\mathrm{X}_{3}$ (persampahan) memiliki korelasi langsung dengan $\mathrm{Y}_{2}$ (sosial ekonomi) sebesar 0.103; $\mathrm{X}_{4}$ (drainase) memiliki korelasi langsung dengan $\mathrm{Y}_{2}$ (sosial ekonomi) sebesar -0.090.

3) Model rantai kausal ketiga

$\mathrm{X}_{1}$ (jalan) memiliki korelasi langsungpada $\mathrm{Y}_{3}$ (tingkat kepadatan permukiman) sebesar $0.405 ; \quad \mathrm{X}_{2}$ (sanitasi) memiliki korelasi langsung dengan $\mathrm{Y}_{3}$ (tingkat kepadatan permukiman) sebesar $-0.092 ; \quad \mathrm{X} 3$ (persampahan) memiliki korelasi langsung dengan $\mathrm{Y}_{3}$ (tingkat kepadatan permukiman)sebesar $\quad 0.191 ; \quad \mathrm{X}_{4}$ (drainase) memiliki korelasi langsung dengan $\mathrm{Y}_{3} \quad$ (tingkat kepadatan permukiman) sebesar 0.064; $\mathrm{Y}_{1}$ (kondisi eksisting wilayah) memiliki korelasi langsung dengan $\mathrm{Y}_{3}$ (tingkat kepadatan permukiman) sebesar $0.463 ; \mathrm{Y}_{2}$ (sosial ekonomi) memiliki korelasi langsung dengan $\mathrm{Y}_{3} \quad$ (tingkat kepadatan permukiman) sebesar 0.121.

4) Pengaruh Tidak Langsung

$\mathrm{X} 1$ memiliki korelasi langsung dengan $\mathrm{Y}_{3}$ (tingkat kepadatan permukiman) melalui $\mathrm{Y}_{1}$ sebesar $0.223 \mathrm{X} 0.463=$ $0.103 ; \mathrm{X}_{2}$ tidak memiliki korelasi langsung dengan $\mathrm{Y} 3$ (tingkat kepadatan permukiman) melalui $Y_{1}$ sebesar 0.679 $\mathrm{X} 0.463=0.314 ; \mathrm{X}_{3}$ tidak memiliki korelasi langsung dengan $\mathrm{Y}_{3}$ (tingkat kepadatan permukiman) melalui $\mathrm{Y}_{1}$ sebesar $0.020 \times 0.463=0.009 ; \mathrm{X}_{4}$ memiliki korelasi langsung dengan $\mathrm{Y}_{3}$ (tingkat kepadatan permukiman) melalui $\mathrm{Y}_{1}$ sebesar $0.030 \times 0.463=0.01 ; \mathrm{X}_{1}$ tidak memiliki korelasi langsung dengan $\mathrm{Y}_{3}$ (tingkat kepadatan permukiman) melalui $\mathrm{Y}_{2}$ sebesar $0.240 \mathrm{X} 0.121=$ $0.029 ; \mathrm{X}_{2}$ tidak memiliki korelasi langsung dengan $\mathrm{Y}_{3}$ (tingkat kepadatan permukiman) melalui $\mathrm{Y}_{2}$ sebesar 0.646 $\mathrm{X} 0.121=0.078 ; \mathrm{X}_{3}$ tidak memiliki korelasi langsung dengan Y3(tingkat kepadatan permukiman) melalui $\mathrm{Y}_{2}$ sebesar $0.103 \mathrm{X} 0.121=0.012 ; \mathrm{X} 4$ tidak memiliki korelasi langsung dengan $\mathrm{Y}_{3}$ (tingkat kepadatan permukiman) melalui $\mathrm{Y}_{2}$ sebesar $-0.090 \mathrm{X} 0.121=$ 0.011 .

Dari hasil uji statistik di atas dapat dijelaskan bahwa :

a) Ketersediaan infrastruktur jalan memiliki korelasi langsung dengan tingkat kepadatan permukiman.

b) Ketersediaan infrastruktur Sanitasi/air limbah tidak memiliki korelasi langsung dengan tingkat kepadatan permukiman. Sanitasi memiliki korelasi langsung 
dengan kondisi eksisting wilayah dan sosial ekonomi. Kondisi eksisting dan sosial ekonomi memiliki korelasi langsung dengan tingkat kepadatan permukiman. Jadi sanitasi memiliki korelasi tidak langsung dengan tingkat kepadatan permukiman.

c) Ketersediaan infrastruktur persampahan memiliki korelasi langsung dengan tingkat kepadatan permukiman.

d) Ketersediaan infrastruktur drainase memiliki korelasi langsung dengan tingkat kepadatan permukiman.

\section{KESIMPULAN}

1. Hasil identifikasi terhadap ketersediaan infrastruktur eksisting di dua kelurahan yaitu Kelurahan Dayan Peken dan Kelurahan Jempong Baru diketahui bahwa:

a. Ketersediaan infrastruktur jalan untuk wilayah dengan tingkat kepadatan tinggi kondisinya lebih buruk dari permukiman dengan tingkat kepadatan rendah.

b. Ketersediaan infrastruktur sanitasi/air limbah di dua kelurahan cukup memadai.

c. Ketersediaan infrastruktur persampahan baik pada permukiman dengan tingkat kepadatan tinggi maupun tingkat kepadatan rendah sudah tidak memadai.

d. Ketersediaan infrastruktur drainase di dua kelurahan masih belum memadai, tidak semua rumah tangga memiliki saluran drainase. Demikian juga dengan kondisi fisik dan aliran, banyak yang mengalami penurunan kualitas.

2. Hasil analisis hubungan yang didapat antara ketersediaan infrastruktur dengan tingkat kepadatan permukiman adalah semakin tinggi tingkat kepadatan permukiman maka semakin tinggi kebutuhan akan ketersediaan infrastruktur. Selengkapnya diuraikan sebagai berikut:

a. Ketersediaan infrastruktur jalan memiliki korelasi langsung dengan tingkat kepadatan permukiman.

b. Ketersediaan infrastruktur sanitasi/ air limbah memiliki korelasi tidak langsung terhadap kepadatan permukiman.

c. Ketersediaan infrastruktur persampahan memiliki korelasi langsung dengan tingkat kepadatan permukiman. d. Ketersediaan infrastruktur drainase memiliki korelasi langsung dengan tingkat kepadatan permukiman.

\section{DAFTAR PUSTAKA}

Gunartha, I.G.E. 2013. Handout mata kuliah metodelogi riset program magister teknik sipil. Program Pascasarjana, Universitas Mataram.

Bintarto, R. 1977. Pengantar geografi kota. Yogyakarta: U.P Spring.

Sugiyono. (2011) Metode penelitian pendekatan kuantitatif, kualitatif, R\&D, Bandung: Alfabeta .

Sunyoto, D. 2012. Model analisis jalur untuk riset ekonomi. Bandung: CV Yrama Widya.

Suparno, S.M., dan Marlina, E. 2006. Perencanaan dan pengembangan perumahan. Bandung: Alfabeta.

Undang-undang Republik Indonesia nomor 4 tahun 1992 tentang perumahan dan permukiman, Jakarta: Departemen Pekerjaan Umum.

Kuswartoyo, Tjuk, dkk,. 2005. Perumahan dan Pemukiman di Indonesia, Bandung : Penerbit ITB.

Misbahuddin., dan Iqbal, H. (2013) Analisis Data Penelitian Dengan Statistik. Jakarta: PT. Bumi Aksara.

Kodoatie, R. J. 2005. Pengantar manajemen infrastruktur. Yogyakarta: Pustaka Pelajar

Trihendradi, C. 2012. SPSS 20 analisis data statistik. Yogyakarta: Andi.

Walizer,M.H. 1991. Metode dan analisis peneliti mencari Hubungan jilid I. Jakarta; Erlangga.

Kepmen Permukiman dan Prasarana Wilayah Nomor : 534/ KPTS/ M/ 2001. 